\title{
A guerra dos mundos virada do avesso: a metáfora política do novo coronavírus
}

\author{
The War of the Worlds Upside Down: \\ The Political Metaphor of the New Coronavirus
}

\author{
Lucas Victor de Oliveira Araújo ${ }^{1}$ \\ Rosanne Bezerra de Araújo ${ }^{2}$
}

DOI: $10.19177 /$ memorare.v8e12021192-203

\begin{abstract}
Resumo: Este artigo investiga A guerra dos mundos estabelecendo uma relação entre a narrativa de H. G. Wells e as guerras e surtos de peste nos séculos posteriores ao romance. Ressaltamos o caráter visionário do autor que antecipa conflitos mundiaiscom potencial bélico, assim como os marcianos fizeram com os humanos no enredo. 0 romance pode ser analisado como uma sátira política diante do contexto da pandemia da Covid-19. Os pensamentos de Slavoj Žižek e Valentin Volóchinov iluminam nossa análise, fazendo-nos refletir sobre a crescente perda de civilidade entre nações e povos e sua representação literária. Além da perspectiva filosófica que enxerga o espírito do tempo de Wells no contexto histórico atual, destacamos, também, a inaptidão dos meios de comunicação e das autoridades diante de eventos trágicos e epidêmicos ao longo da nossa História.
\end{abstract}

Palavras-chave: H. G. Wells. Pandemia. Sátira política.

\begin{abstract}
This paper investigates The war of the worlds by establishing a relationship between H.G. Wells' narrative and the wars and plague outbreaks in the centuries following the novel. We emphasize the visionary character of the author who anticipates world conflicts with war potential, just as the Martians did with humans. The novel can be analyzed as a political satire in the context of the Covid-19 pandemic. Slavoj Žižek's and Valentin Voloshinov's thoughts illuminate our analysis, making us reflect on the increasing loss of civility among nations and peoples and its literary representation. In addition to the philosophical perspective that sees Wells' spirit of time in the present historical context, we also highlight the inability of the media and authorities to cope with tragic and epidemic events throughout our history.
\end{abstract}

Keywords: H. G. Wells. Pandemic. Political satire.

\footnotetext{
1 Mestrando do Programa de Pós-graduação em Estudos da Linguagem da UFRN, cuja pesquisa recebe o apoio da Coordenação de Aperfeiçoamento de Pessoal de Nível Superior (CAPES). lucasvictoroaraujo@gmail.com

2 Professora do Departamento de Línguas e Literaturas Estrangeiras Modernas e do Programa de Pós-graduação em Estudos da Linguagem da UFRN. rosanne.bezerra@cchla.ufrn.br
} 
O mundo não é mais dos seres humanos, mas eles ainda o habitam.

(Pedro Duarte)

\section{Introdução}

${ }^{3}$ Prefácio do livro traduzido por Leonardo Castilhone, pela editora Martin Claret. 


\section{Pandemia num contexto global}

Neste primeiro tópico de nosso artigo, reunimos pensamentos acerca da complexidade social dos efeitos da pandemia no mundo atual, com suas lógicas sociais, políticas, econômicas e psíquicas. Esboçamos, aqui, uma breve visão global de alguns escritores que dedicaram o seu tempo em 2020, precisamente entre fevereiro e março, logo no início da pandemia, para refletir sobre a emergência sanitária mais importante do nosso tempo.

Alguns autores apontam para a nacionalização dos governos, bem como para um neoliberalismo que se veste descaradamente como um estado de guerra. Judith Butler em "El Capitalismo Tiene sus Limites" (2020) avisa-nos do reforço das políticas nacionais, do encerramento das fronteiras e do perigo da chegada de empresários ansiosos por capitalizar o sofrimento global. De acordo com Butler, o vírus não discrimina. A desigualdade social e econômica assegura a discriminação. De fato, o sistema capitalista valoriza a vida de uns e despreza a de outros. No seu ensaio intitulado "Sobre la Situación Epidémica" (2020), Alain Badiou sublinha que para combater um nacionalismo repugnante, os grupos de esquerda deveriam pensar em novas figuras políticas, visando a saúde pública e projetos educativos que promovam a igualdade. Só assim poderíamos lutar contra a ideologia neoliberal. Do mesmo modo, no seu ensaio "Política Anticapitalista em Tiempos de Covid-19" (2020), David Harvey diz que o modelo neoliberal prova todos os dias que o seu modelo de acumulação fictícia de capital é uma farsa. A política de austeridade do neoliberalismo foi concebida para financiar cortes fiscais, bem como subsídios para as grandes empresas dos ricos, quando, de fato, deveriam estar a angariar fundos em defesa da saúde pública. Harvey salienta também que as grandes farmácias não investem numa política de prevenção porque essas empresas querem conceber curas futuras enquanto, no presente, continuam a lucrar com o número de pessoas doentes.

Esses autores estão de acordo uns com os outros. Embora com argumentos diferentes - tais como a defesa de Žižek da ideia de que a pandemia possa representar um golpe mortal para o sistema capitalista -, todos eles procuram refletir sobre as recentes controvérsias em torno dos cenários que se abrem com a pandemia do novo vírus, expondo suas opiniões sobre o presente e as hipóteses sobre o futuro. Esses ensaios estão compilados no livro Sopa de Wuhan (2020), uma iniciativa editorial que se destina a durar toda a quarentena. 0 livro traz as ideias de autores de diferentes países, destacando não só considerações sobre a Covid-19, mas também as características de uma pandemia de classe, gênero e raça. Em relação à América Latina, mesmo antes do novo coronavírus, comunidades inteiras sempre tiveram que enfrentar outras enfermidades como o câncer, a desnutrição, a dengue, e assim por diante. Muitas pessoas que têm vivido em áreas insalubres, sem saneamento básico ou acesso à água, não têm acesso a hospitais. A pandemia chegou para somar-se aos vários males já existentes em comunidades pobres. Como diz Markus Gabriel (2020, p. 131), todos os virologistas procuram encontrar uma vacina contra o vírus recente, a fim de salvar vidas: "Pero ¿quién los escucha cuando nos dicen que cada 
año más de 200.000 niños mueren de diarrea viral porque no tienen agua potable? ¿Por qué nadie se interesa por esos niños? Por desgracia, la respuesta es clara: porque no están en Alemania, España, Francia o Italia." 4

Na ficção, muitos autores vêm produzindo narrativas de distopias, com obras de especulação política e científica, a exemplo de Wells. Por meio de sua obra visionária e pessimista, foi possível antecipar o encaminhamento da humanidade para a realização das Guerras Mundiais. Em A guerra dos mundos, o leitor se depara com uma visão poderosa e apocalíptica do planeta Terra ao ser invadido por marcianos.

Dentre as possibilidades de análise deste romance, destacamos a sátira política, bem como o sinal de alerta diante do perigo iminente de um poder irresponsável e descontrolado de cientistas. Como sabemos, a ciência que descobriu vacinas no passado também foi capaz de criar a potência nuclear genocida. Para Wells, o progresso científico deve caminhar lado a lado do progresso social. Do contrário, a luta de classes se perpetuará e sempre teremos populações ou nações inteiras subjugadas e excluídas do processo capitalista global.

\section{Um autor visionário}

É possível afirmar que o gênero "ficção científica" surgiu com Mary Shelley. Sabemos que após a publicação de Frankenstein (1818) a ficção sofreu um grande impacto. Shelley é frequentemente reconhecida como a romancista que primeiro abordou o foco científico na ficção. No entanto, foi somente em 1895, com a Máquina do tempo de H. G. Wells, que o romance de ficção científica teve o seu apogeu e se popularizou. Aquilo que se conhecia por "romance científico" no século XIX passou a ganhar um novo termo: "ficção científica".

Considerado o pai da ficção científica, Wells apresenta uma crítica arguta da sociedade em que vivia, questionando o fato de algumas nações insistirem em dominar outras, denunciando, assim, a expansão colonial europeia que levava a morte a tantos outros continentes. Em particular, o inabalável império inglês só poderia ser sacudido mediante uma força que viesse de fora - de outro planeta (Marte). Tendo em mente tal cenário, o autor escreveu A guerra dos mundos. Žižek ressalta que, conforme Wells, o enredo do livro

surgiu de uma discussão com seu irmão, Frank, a respeito do efeito catastrófico dos ingleses para o povo indígena na ilha da Tasmânia. Oque ocorreria, ele se perguntava, se os marcianos fizessem com a Inglaterra o que os ingleses haviam feito com aquele povo? Os tasmanianos nativos, contudo, não puderam contar com os patógenos letais para derrotar seus invasores. Talvez as epidemias que ameaçam dizimar a humanidade devessem ser tratadas como a história de Wells virada ao avesso: os "invasores marcianos" impiedosamente explorando e destruindo a vida no planeta somos nós mesmos, a humanidade (ŽIŽEK, 2020, p. 31).

Sabemos que imigrantes europeus exterminaram povos, considerando-os de raça fraca, a exemplo do que ocorreu no território da Tasmânia. Além disso, nossa espécie humana vem causando danos

\footnotetext{
4 "Mas quem nos daria ouvidos quando nos dizem que todos os anos mais de 200.000 crianças morrem de diarreia viral por não terem água limpa? Por que ninguém se interessa por essas crianças? Infelizmente, a resposta é clara: porque elas não estão na Alemanha, Espanha, França ou Itália" (2020, p. 131. Tradução nossa).
} 
irreparáveis a outras espécies do planeta. 0 narrador de Wells reflete com discernimento antes de sentenciar os marcianos como inimigos, quando da chegada enigmática destes, logo no primeiro capítulo:

Antes que os julguemos com dureza e de forma precipitada, devemos nos lembrar das destruições cruéis e implacáveis que nossa espécie causou, não apenas contra animais, como os extintos bisões e os pássaros dodô, mas sobre raças presumidamente inferiores." (WELLS, 2019, p. 21).

Para além da consciência ambiental, social e política de Wells, destacamos, também, o caráter profético que o autor imprime a sua obra ao antecipar a batalha entre nações, como a humanidade testemunhou com aviões lançando bombas na Segunda Guerra Mundial, dizimando populações, semelhante ao que os marcianos fizeram com os homens em A guerra dos mundos. Os habitantes de Marte desejavam tomar a Terra com o interesse nos recursos naturais ali encontrados, além da vantagem de o globo terrestre ser cercado pelo calor e pela luz do Sol. Invejosos, os alienígenas decidiram empreender uma missão colonizadora.

0 enredo do romance traz o início do século XX com cilindros sendo arremessados de Marte em direção à Terra, o que, inicialmente, os humanos tomam por meteoros. Cada cilindro continha uma quantidade de marcianos com máquinas poderosas para a destruição dos habitantes da Terra. Tais máquinas, de certa forma, anteciparam o potencial bélico desse século, como os veículos blindados e os canhões utilizados por alemães e soviéticos na Segunda Guerra Mundial. Como sabemos, mísseis e bombas voadoras fizeram parte da artilharia estratégica desses países.

A perda de civilidade, empatia e solidariedade é outro ponto marcante no romance. À medida que a população fugia da cidade para escapar dos ataques marcianos, observamos que dificilmente os humanos se ajudavam. No êxodo em busca de um lugar seguro, as pessoas ameaçavam umas às outras, disputando até mesmo a comida. Personagens como o vigário e o artilheiro são bons exemplos para ilustrar a insanidade em tempos de guerras e pandemias. Ambos representam o oposto do que deveria ser, na prática, o seu ofício. No lugar de solidário, o padre revela-se um avarento. Quanto ao artilheiro, em vez de unir esforços e um planejamento contra o inimigo comum, prefere isolar-se e tramar um plano para juntar-se aos marcianos e subjugar os humanos, com o intuito de salvar a própria pele.

Refletindo sobre essa perda de civilidade retratada no romance, inúmeras indagações surgem a respeito do momento pandêmico que vivemos no presente. Será que num mundo pós-pandemia teríamos indivíduos mais solidários, como chega a sinalizar Žižek? Aprenderíamos a ter compaixão pelo próximo?

\section{${ }_{4}$ A guerra dos mundos}

0 romance foi escrito num período marcado pela instabilidade política na Europa. A invasão dos marcianos pode ser entendida como a antecipação do que viria a ocorrer nas décadas seguintes à publicação do romance, quando nações europeias passaram a invadir territórios vizinhos em busca de expansão territorial. 
A guerra dos mundos descreve a invasão da Terra por extraterrestres vindos de Marte. 0 enredo se passa principalmente na zona rural da Inglaterra. 0 romance é narrado por um protagonista sem nome que tenta sobreviver à hecatombe causada pelos marcianos. Os personagens do livro também não recebem nome. São identificados por sua classe, profissão, ou posição social: o artilheiro, o vigário, o barqueiro, o soldado, e assim por diante. Tal característica reforça o anonimato dos indivíduos, já que a guerra aterrorizante torna todos iguais diante do medo da morte.

A narrativa é dividida em duas partes, a primeira trata da chegada dos invasores enquanto a segunda expõe a Terra sob o domínio desses seres. Na segunda parte, o movimento de avançar dos marcianos contrasta com o de fugir dos humanos: "[...] estão avançando lentamente em direção a Londres, destruindo tudo em seu caminho. É impossível detê-los. Não há como se safar da Fumaça Preta, senão fugindo imediatamente." (WELLS, 2019, p. 141-142).

"Avançar" e "recuar" é a tática de guerra que move todas as cenas e o desenvolvimento do romance. 0 narrador registra o passo a passo da guerra, mantendo um olhar distanciado, desde o início, como se estivesse descrevendo um evento ocorrido, assim como o fazem os comunicadores dos jornais da época. No trecho seguinte, o narrador reflete sobre o seu sentimento de apatia diante dos primeiros acontecimentos, afinal tudo parecia surreal e sem sentido:

Talvez eu seja um homem de humor atípico. Não sei até que ponto minha experiência é comum. Às vezes sofro de um estranho senso de indiferença perante mim mesmo e o mundo ao meu redor; sinto como se observasse tudo em terceira pessoa, de algum lugar extraordinariamente remoto, longe do tempo, longe do espaço, longe da agitação e da tragédia atuais. (WELLS, 2019, p. 62).

No decorrer dos capítulos, a presença dos marcianos se intensifica, dando sequência à destruição e à carnificina. Diante da devastação, uma procissão de refugiados se formava para invadir outras cidades. A multidão de fugitivos se avolumava na tentativa desesperada de escapar dos marcianos e de suas máquinas (trípodes aracnoides) potentes, que lançavam raios carbonizadores nos seres vivos e esmagavam a vegetação por onde passavam. No meio dessa multidão havia operários, comerciantes, mulheres, idosos, crianças. E por mais diversa que fosse essa população, uma coisa era comum a todos - o medo da morte.

\section{Histórias, notícias, boatos}

Faz-se importante observar o comportamento da população em tempos de guerras e pandemias, bem como identificar as falas, seja do povo nas ruas, seja dos meios de comunicação da época, visando a uma aproximação entre a reação dos homens no século XIX e a reação das pessoas no contexto atual da pandemia do novo coronavírus no século XXI. Como caracterizar o discurso em ambos?

No artigo "What the Great Pandemic Novels Teachus"5, Orphan Pamuk defende que há semelhanças na maneira como as sociedades

\footnotetext{
5 Orphan Pamuk, "What the Great Pandemic Novels Teach us", The New York Times, 23 abr. 2020. Disponível em: https://www.nytimes.com/2020/04/23/opinion/sunday/coronavirus-orhan-pamuk.html; acesso em: 19 nov. 2020.
} 
reagiram e vêm reagindo às grandes tragédias e surtos de peste ao longo da história da humanidade. De forma geral, autoridades negam as tragédias logo no início. Além do negacionismo, boa parte dos cidadãos ignora os fatos ${ }^{6}$ tende a espalhar boatos e subestimar a catástrofe que está prestes a acontecer. Essas evidências revelam o despreparo das autoridades e dos meios de comunicação.

Com vistas a reforçar tal entendimento, mantemos o foco de nossa análise do romance dando destaque a trechos que noticiam a presença dos marcianos na Terra. À medida que citamos as passagens da narrativa, buscamos estabelecer relações entre elas e a situação da pandemia da Covid-19, no intuito de investigar como a reação humana atual não difere tanto da reação da população retratada por Wells. Para tanto, nos utilizamos da perspectiva dialógica, representada aqui pelo filósofo da linguagem Valentin Volóchinov, com o intuito de demonstrar que os discursos da vida são incorporados à literatura de modo que a comparação feita pelo filósofo esloveno se justifica também nos campos da filosofia da linguagem e teoria literária.

No primeiro capítulo, "A véspera da guerra”, o narrador informa que antes da invasão dos alienígenas, os leitores britânicos já tinham informação a respeito de um jato de fogo que havia resultado numa tempestade de fumaça expelida repentinamente de Marte em direção à Terra. No entanto, "no dia seguinte, não havia nada sobre o assunto nos jornais, exceto por uma pequena nota no Daily Telegraph, e o mundo permaneceu ignorante diante de um dos mais graves perigos que já ameaçaram a raça humana." (WELLS, 2019, p. 23). Mais adiante, o narrador diz:

Finalmente, até mesmo os grandes jornais se ocuparam daquelas perturbações, então notícias passaram a aparecer aqui, ali e em todo lugar, relativas aos vulcões sobre Marte. O periódico sério-cômico Punch, lembro-me bem, fez um uso inteligente do acontecido na charge política. (WELLS, 2019, p. 26).

No capítulo seguinte, "A estrela cadente", os jornais se mobilizaram para que o público pudesse receber a notícia. Foi noticiado que vários homens tinham se dirigido até o local onde havia caído o cilindro para ver os "homens mortos de Marte", eis como a notícia foi resumida, conforme observa o narrador: "Foi assim que a história ficou conhecida. Ouvi-a pela primeira vez pelos gritos do jornaleiro por volta das quinze para as nove, quando saí para comprar meu Daily Chronicle." (WELLS, 2019, p. 33). Logo depois, as primeiras manchetes passaram a trazer informações incertas e chocantes. Contudo, a maior parte dos cidadãos permaneceu indiferente. As pessoas continuavam suas rotinas como se o perigo iminente não existisse, como bem reflete o protagonista no seu relato: "Hoje, parece-me quase inacreditável e absurdo imaginar que, mesmo diante daquele terrível destino à espreita, os homens continuaram preocupados com mesquinharias do dia a dia." (WELLS, 2019, p. 26). 0 comportamento das pessoas demonstrava não haver uma grave ameaça pairando no ar:

${ }^{6}$ No romance de Wells, os cidadãos tinham pouco ou nenhum conhecimento sobre astronomia. No início da pandemia atual, em 2020, muitas pessoas ignoraram completamente o nível de contágio e letalidade do novo coronavírus. 
Talvez houvesse rumores nas ruas do vilarejo, uma história com um mesmo assunto nos bares, um mensageiro aqui e ali, ou mesmo uma testemunha ocular dos recentes ocorridos, causando agitações, gritarias e correrias: mas de modo geral a rotina diária de trabalhar, comer, beber e dormir continuava como de hábito. (WELLS, 2019, p. 70).

Os jornais da época continuavam divulgando artigos sobre Marte e a presença enigmática dos marcianos no planeta Terra. Relatavam que os invasores pareciam não querer ou não conseguir sair do fosso no qual haviam caído, dentro de cilindros, na sua chegada ao planeta. Os editores-chefes de alguns jornais tinham que lidar com o desconhecido e evitar a divulgação de notícias precipitadas e infundadas. Por outro lado, havia, também, jornais que apostavam em manchetes sensacionalistas. 0 protagonista segue descrevendo suas impressões das matérias dos jornais e da atitude das pessoas que se dividiam em reações que variavam do pânico à indiferença.

Em seu ensaio a respeito do que os romances sobre pandemias nos ensinam, Pamuk observa que nossas respostas ao desconhecido são demasiado espontâneas, de modo que rumores e falsos boatos logo surgem, propagando a desinformação. 0 fato de nos dias atuais termos acesso às notícias de forma rápida, com o advento da tecnologia, da internet, de mídias sociais, variados meios de comunicação etc., parece não mudar o nosso comportamento humano universal de demonstrar um completo despreparo diante de um novo evento. Desde os tempos da Renascença pragas e guerras são acompanhadas de rebeliões e pânico.

Voltando-se para o século XXI, um dos primeiros boatos que surgem diante de um evento trágico é culpar uma nação, um povo, um grupo. Assim, quando as pragas e conflitos entre países emergem, é preciso criar um inimigo para promover uma ação conjunta de retaliação contra o culpado. Isso aconteceu em 2001 com a queda das torres gêmeas do World Trade Center nos Estados Unidos, fato que fez o mundo ver os muçulmanos como terroristas. Com a chegada do Sars$\mathrm{CoV}-2$, determinadas nações passaram a condenar a China pelo fato de o vírus ter se originado ali. Esse sentimento de xenofobia, de aversão a uma nação vizinha, também é encontrado em A guerra dos mundos:

A moça nunca esteve fora da Inglaterra, preferia morrer a ficar desamparada num país estrangeiro, e assim por diante. Ela parecia, pobre mulher, imaginar que os franceses e os marcianos seriam praticamente iguais. Foi ficando mais e mais histérica, apavorada e deprimida a cada minuto dos dias seguintes da jornada. (2019, p. 180).

Essa passagem do romance é encontrada no capítulo "O êxodo de Londres", quando uma grande procissão de refugiados busca escapar da cidade já praticamente sob o domínio dos marcianos. Grandes grupos aguardam embarcações para levá-los embora dali, porém, uma moça no grupo, ao olhar o mar a sua frente, entra em pânico diante da ideia de deixar a Inglaterra.

Dessa forma, é possível perceber como a narrativa literária de Wells é perpassada pelos discursos sociais da vida real, o que se justifica pelo fato de a literatura ser uma forma de arte cujo material é a linguagem e esta realiza-se nas vozes do mundo social. De fato, Volóchinov (2019, p. 113) defende que "a arte é imanentemente social: o meio social extra-artístico, ao influenciá-la de fora, encontra nela uma

Memorare, Tubarão, v. 8, n. 1, jan./jun. 2021. ISSN: 2358-0593 
imediata resposta interior. Nesse caso, não é o alheio que age sobre o alheio, mas uma formação social sobre a outra.". Os diferentes discursos são orientados por diversas ideologias, termo que no dialogismo faz referência ao conjunto de ideias acerca de um tópico ou área (VOLÓCHINOV, 2017); e podem ser utilizados com os mesmos propósitos dentro da narrativa literária. No caso do romance de Wells, podemos perceber o poder do discurso de autoridade da narrativa jornalística, o qual se beneficia da premissa básica de que o jornalismo lida sempre com fatos objetivos e com a maior neutralidade possível. Dessa forma, se os jornais não fazem alarde, logo, não deve haver motivo para alarde. A natureza factual do jornalismo acaba por se mostrar, no contexto wellsiano, como uma profecia que se autoconcretiza. 0 pânico é evitado no início, pois o jornal nas ruas afirma não haver pânico. Somente quando a violência explode no país e os marcianos começam a exterminar os humanos é que a dimensão apocalíptica da invasão se torna evidente para a população.

\section{A lição que fica após um evento trágico}

Žižek (2020) e Pamuk (2020) afirmam que o medo desperta em nós dois sentimentos contraditórios. Um deles é a solidão, a necessidade de recolhimento para proteger-se da ameaça lá fora (seja alienígenas ou patógenos) que possa nos levar à morte. 0 outro, oposto ao isolamento, é o sentimento de humildade que nos encoraja a praticar a solidariedade.

Em relação ao contexto atual, conforme Žižek (2020), a única maneira de evitar a barbárie global é criar uma nova humanidade, uma nova subjetividade, capaz de unificar povos e nações, expressando amor e solidariedade - uma espécie de reinvenção do ideal do comunismo. Nesse novo tipo de humanidade, as nações pobres iriam crescer e a exploração seria abolida. Consonante com o pensamento do esloveno, Pamuk defende a necessidade de despertar o sentimento de humildade para que possamos acolher nossos semelhantes de forma fraterna e solidária no novo cenário que surgirá num futuro próximo - o mundo pós-pandemia.

Em A guerra dos mundos sublinhamos reflexões pertinentes do narrador ao comparar o domínio dos marcianos sobre a raça humana ao fato de nós exercermos o domínio sobre outras espécies. Vejamos uma breve descrição de como os marcianos se nutriam:

Eles eram cabeças - somente cabeças. Não tinham entranhas. Não comiam e muito menor digeriam. Em vez disso, eles sorviam o sangue vivo e fresco de outras criaturas, injetando-o, diretamente em suas veias [...]

Só de pensar nisso, sem dúvida alguma, sentimos uma terrível repulsa; mas, ao mesmo tempo, penso que deveríamos nos lembrar de quão repulsivos nossos hábitos carnívoros pareceriam a um coelho inteligente. (WELLS, 2019, p. 207-208).

Essa reflexão crítica à nossa alimentação carnívora sinaliza, já no século XIX, para o que ainda guardamos em nós de predadores e incivilizados, como também alerta para o perigo do extermínio de uma espécie por outra. Tal exemplo é apenas um dentre tantos outros momentos nos quais o narrador expressa o seu entendimento crítico a 
respeito da humanidade. Lembremo-nos de que a área de estudos do narrador é filosofia especulativa. Portanto, ele não pretende somente esboçar uma análise apurada da fisiologia dos extraterrestres e dos estragos decorridos da invasão. 0 narrador preocupa-se sobretudo em diagnosticar e caracterizar atitudes que possam ser consideradas humanas, civilizadas ou não. Tal preocupação é observada antes, durante e após a invasão dos alienígenas. O filósofo sobrevivente conta a história demonstrando consciência e discernimento diante de toda a sua jornada nessa guerra.

Já caminhando para o final do seu relato, o narrador-filósofo escreve: "Seguramente, se aprendemos alguma coisa com essa guerra, foi que ela nos ensinou a ter compaixão - compaixão pelas almas menos evoluídas que suportam nosso domínio." (WELLS, 2019, p. 247). Compaixão, solidariedade e humildade são lições que Wells, Žižek e Pamuk consideram determinantes diante dos eventos trágicos ao longo da História. É preciso, cada vez mais, despertar para o coletivo. Afinal, mesmo na mais profunda solidão, nunca estamos sozinhos - nem na Terra e nem no universo.

\section{Considerações finais}

Conforme o título do artigo e o objetivo deste estudo, buscamos evidenciar o livro de Wells, por intermédio da visão dialógica de Volóchinov, como uma metáfora política da pandemia atual, afinal, "podemos ler a epidemia em curso da Covid-19 como uma versão invertida de A guerra dos mundos" (ŽIŽEK, 2020, p. 30). Os mecanismos discursivos identificáveis na narrativa de Wells se fazem presentes na contemporaneidade. E como explicar essa inversão? Ora, os europeus durante muito tempo foram os invasores, colonizadores e imperialistas a subjugar um povo, uma nação, uma etnia. Como sabemos, o império de nações coloniais (Alemanha, França, Inglaterra) foi construído às custas da divisão do continente africano entre elas ao longo dos séculos. Esses colonizadores atuaram como marcianos de Wells invadindo o território alheio. Séculos depois, outras nações perpetuam as mesmas estruturas imperialistas de exploração e continuam promovendo guerras e conflitos, como mencionamos no caso da retaliação dos Estados Unidos devido aos ataques terroristas de 11 de setembro de2001. Agora vivemos um outro tipo de guerra às avessas, na qual nós humanos, quer sejamos de países desenvolvidos ou não, estamos juntos no mesmo barco contra um inimigo comum, não um marciano, mas uma ameaça invisível, um vírus a dizimar seres humanos que não possuem um sistema imunológico forte o suficiente para combater suas mutações. É fácil imaginar que um inimigo comum fosse unir as nações e, citando Martin Luther King, Žižek (2020, p. 32-33) diz que "embora tenhamos chegado em embarcações diferentes, estamos todos no mesmo barco". Mas será que estamos mesmo? Talvez estejamos no mesmo oceano de incertezas, mas não no mesmo barco, já que a divisão entre classes e entre nações ricas e pobres permanece abismal. Assim como os personagens de Wells, as mentalidades de cada grupo social ante a ameaça do inimigo viral são díspares, assim como suas capacidades de se proteger. A humanidade segue em barcos isolados, com o fechamento das fronteiras e o medo do próximo. 
Os marcianos do romance de Wells foram invasores implacáveis com suas máquinas gigantescas que pisoteavam os humanos; algo parecido ao que fazemos com um formigueiro. Semelhantes a tais máquinas, pouco nos importamos com a extinção de várias espécies no planeta. E não precisamos empreender jornadas a outros mundos. É aqui mesmo, entre nossos iguais, que invadimos terras alheias, colonizamos povos e praticamos genocídios, visando a exploração de recursos muitas vezes não renováveis como o petróleo, atendendo apenas aos interesses do mercado global. Seríamos, portanto, os próprios destruidores de nossa espécie? Desequilibramos o planeta por conta da ganância, maldade e indiferença. Criamos a energia nuclear, bem como vírus/ideologias indestrutíveis, a exemplo do Fascismo e do Nazismo, contra os quais não há vacina. A mensagem de alerta geralmente presente na ficção científica e especialmente na obra de Wells aqui analisada avançou dos potenciais perigos da ciência sem ética para os atuais desastres de uma "ética" que ignora a ciência em função de ideologias de exploração comprovadamente destrutivas para nós e o planeta como um todo.

Por fim, a pandemia atual, como reforça o filósofo esloveno, não guarda nenhum significado profundo. 0 difícil para todos nós é aceitar que, "na ordem mais ampla das coisas, somos uma espécie sem importância." (ŽIŽEK, 2019, p. 32).

\section{Referências}

BADIOU, A. Sobre La Situación Epidémica. In Sopa de Wuhan: Pensamiento Contemporáneo en Tiempos de Pandemia. P. Amadeo \& ASPO (Aislamiento Social Preventivo y Obligatorio), 2020. (pp. 67-78). Disponível em: https://bit.ly/sopadewuhan. Acesso em 31 mar. 2021.

BUTLER, J. El Capitalismo Tiene sus Limites. In Sopa de Wuhan: Pensamiento Contemporáneo en Tiempos de Pandemia. P. Amadeo \& ASPO (Aislamiento Social Preventivo y Obligatorio), 2020. (pp. 59-66). Disponível em: https://bit.ly/sopadewuhan. Acesso em 31 mar. 2021.

DUARTE, P. A pandemia e o exílio do mundo. Rio de Janeiro: Bazar do Tempo, 2020.

GABRIEL, M. (2020). El Virus, el Sistema Letal y Algunas Pistas para Después de la Pandemia. In Sopa de Wuhan: Pensamiento Contemporáneo en Tiempos de Pandemia. P. Amadeo \& ASPO (Aislamiento Social Preventivo y Obligatorio), 2020. (pp. 129-134). Disponível em: https://bit.ly/sopadewuhan. Acesso em 31 mar. 2021.

HARVEY, D. Política Anticapitalista em Tiempos de Covid-19. In Sopa de Wuhan: Pensamiento Contemporáneo en Tiempos de Pandemia. P. Amadeo \& ASPO (Aislamiento Social Preventivo y Obligatorio), 2020. (pp. 79-96). Disponível em: https://bit.ly/sopadewuhan. Acesso em 31 mar. 2021.

PAMUK, O. "What the Great Pandemic Novels Teach us", The New York Times, 23 abr. 2020. Disponível em: https://www.nytimes.com/2020/04/23/opinion/sunday/coronavirusorhan-pamuk.html. Acesso em 19 nov. 2020. 
VOLÓCHINOV, Valentin. A palavra na vida e a palavra na poesia: ensaios, artigos, resenhas e poemas. Organização, tradução, ensaio introdutório e notas de Sheila Grillo e Ekaterina Vólkova Américo. São Paulo/SP, v. 34, 2019.

VOLÓCHINOV, Valentin. Marxismo e filosofia da linguagem. Tradução, notas e glossário de Sheila Grillo e Ekaterina Vólkova Américo. São Paulo: Editora 34, 2017.

WELLS, H. G. A guerra dos mundos. São Paulo: Martin Claret, 2019.

ŽIŽEK, S. Pandemia: Covid-19 e a reinvenção do Comunismo. São Paulo: Boitempo, 2020.

ŽIŽEK, S. Coronavirus es un Golpe al Capitalismo al Estilo de 'Kill Bill' y Podría Conducir a la Reinvención del Comunismo. In Sopa de Wuhan: Pensamiento Contemporáneo en Tiempos de Pandemia. P. Amadeo \& ASPO (Aislamiento Social Preventivo y Obligatorio), 2020. (pp. 21-28). Disponível em https://bit.ly/sopadewuhan. Acesso em 31 mar. 2021.

Artigo enviado em: 08/05/2021. Aprovado em: 25/05/2021. 